ARTICLE

Received 17 Sep 2012 | Accepted 21 Mar 2013 | Published 7 May $2013 \quad$ DOl: 10.1038/ncomms2793

\title{
An isoform of retinoid-related orphan receptor $\beta$ directs differentiation of retinal amacrine and horizontal interneurons
}

Hong $\mathrm{Liu}^{1}$, Soo-Young $\mathrm{Kim}^{2}$, Yulong Fu${ }^{1}$, Xuefeng $\mathrm{Wu}^{1}$, Lily $\mathrm{Ng}^{1}$, Anand Swaroop ${ }^{2} \&$ Douglas Forrest ${ }^{1}$

\begin{abstract}
Amacrine and horizontal interneurons integrate visual information as it is relayed through the retina from the photoreceptors to the ganglion cells. The early steps that generate these interneuron networks remain unclear. Here we show that a distinct retinoid-related orphan nuclear receptor $\beta 1$ (ROR $\beta 1$ ) isoform encoded by the retinoid-related orphan nuclear receptor $\beta$ gene (Rorb) is critical for both amacrine and horizontal cell differentiation in mice. A fluorescent protein cassette targeted into Rorb revealed ROR $\beta 1$ as a novel marker of immature amacrine and horizontal cells and of undifferentiated, dividing progenitor cells. RORß1-deficient mice lose expression of pancreas-specific transcription factor 1a (Ptf1a) but retain forkhead box $n 4$ factor (Foxn4), two early-acting factors necessary for amacrine and horizontal cell generation. RORß1 and Foxn4 synergistically induce Ptfla expression, suggesting a central role for ROR $\beta 1$ in a transcriptional hierarchy that directs this interneuron differentiation pathway. Moreover, ectopic ROR $\beta 1$ expression in neonatal retina promotes amacrine cell differentiation.
\end{abstract}

\footnotetext{
${ }^{1}$ Laboratory of Endocrinology and Receptor Biology, National Institutes of Health, NIDDK, 10 Center Drive, Bethesda, Maryland 20892-1772, USA.

${ }^{2}$ Neurobiology, Neurodegeneration and Repair Laboratory, National Institutes of Health, NEl, Bethesda, Maryland 20892-1772, USA. Correspondence and requests for materials should be addressed to D.F. (email: forrestd@niddk.nih.gov).
} 
A macrine and horizontal cells integrate visual information as it is relayed through the retinal layers from the lightsensitive photoreceptors to the ganglion cells that form the optic nerve. Horizontal cells modify synaptic transmission between photoreceptors and bipolar cells whereas amacrine cells modify transmission between bipolar and ganglion cells ${ }^{1}$. These inhibitory interneuron networks are critical for visual function but the controls that generate amacrine and horizontal cells are incompletely understood.

The different cell types of the neural retina are derived from multipotent progenitor cells $s^{2-5}$. Transcription factors in dividing progenitor cells or in newly post-mitotic precursor cells often determine retinal cell differentiation fates ${ }^{6-8}$. The forkhead box factor forkhead box $\mathrm{n} 4$ factor (Foxn4) and the basic helix-loophelix (bHLH) factor pancreas-specific transcription factor la (Ptf1a) are required for differentiation of both horizontal and amacrine cells in mice, suggesting that a common transcriptional signal induces the formation of both interneuron classes ${ }^{9-11}$. The nature of this initial stimulus is unclear but Foxn4 expression in progenitor cells is succeeded by Ptfla expression in postmitotic precursor cells ${ }^{9-13}$, suggesting the involvement of a transcriptional hierarchy. In addition, the homeodomain protein Proxl is required for horizontal cell differentiation ${ }^{14}$, whereas bHLH proteins Neurod1 (Nd1) and Neurod4 (Nd4, or Math3) are required for amacrine cell differentiation ${ }^{15}$, suggesting that other controls promote divergence of amacrine and horizontal cell lineages. Other transcription factors of the $\mathrm{bHLH}^{16-18}$, nonbasic $\mathrm{HLH}^{19}$, homeodomain ${ }^{20-22}$ and other families ${ }^{23-25}$ further influence diversity in amacrine cell sub-lineages.

The retinoid-related orphan nuclear receptor $\beta$ gene (Rorb, Nr1f2) mediates several neurodevelopmental functions. A total
Rorb deletion impaired circadian behaviour, hindlimb motor control $^{26}$, opsin induction in cone photoreceptors ${ }^{27}$ and differentiation of rod photoreceptors ${ }^{28}$. The means by which developmental genes such as Rorb are able to control diverse cellular functions are often unclear. Rorb encodes two N-terminal isoforms, $\operatorname{ROR} \beta 1$ and $\operatorname{ROR} \beta 2$, with undefined functions ${ }^{29}$.

Here, we report a key role for $\operatorname{ROR} \beta 1$ in amacrine and horizontal cell differentiation. Moreover, ROR $\beta 1$ and Foxn4 synergistically activate the Ptfla gene, suggesting that cooperation between this orphan receptor isoform and Foxn4 stimulates amacrine and horizontal cell generation.

\section{Results}

Differential expression of RORß1 and RORß2 isoforms. To investigate specific functions for the isoforms encoded by Rorb, we analysed the expression of ROR $\beta 1$ and ROR $\beta 2$ mRNA during retinal development in mice (Fig. 1a). ROR $\beta 1$ mRNA displayed a broad peak between mid-embryonic stages and the first postnatal week. ROR $\beta 1$ mRNA expression then declined and was maintained at lower levels into adulthood. In contrast, ROR $\beta 2$ mRNA was first detected at late embryonic stages and displayed a prominent rise over the first postnatal week. These contrasting expression profiles suggested that each isoform mediates specific functions in retinal development with $\operatorname{ROR} \beta 1$ serving a unique role at earlier stages of neurogenesis.

Deletion of the RORß1 isoform. To determine the role of ROR $\beta 1$ and to facilitate detection of its expression at the cellular level, we replaced the ROR $\beta 1$-specific exon with a green fluorescent protein (gfp) cassette in mice. ROR $\beta 1$ and $\operatorname{ROR} \beta 2$ are a

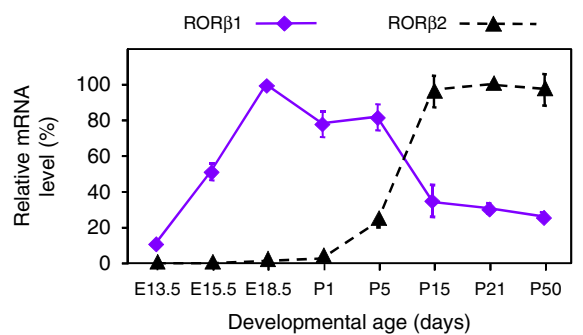

b

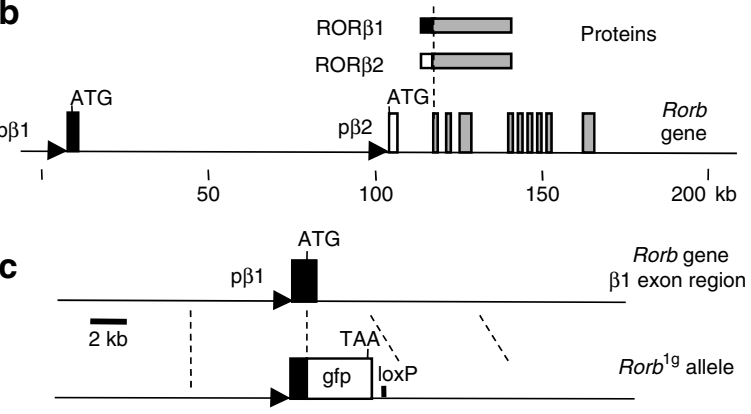

d

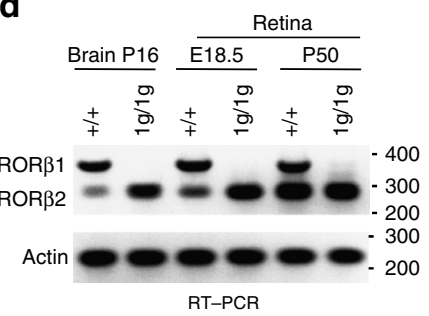

e

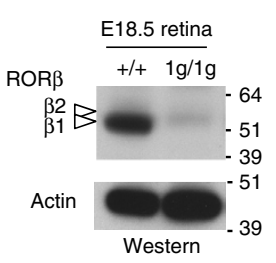

f

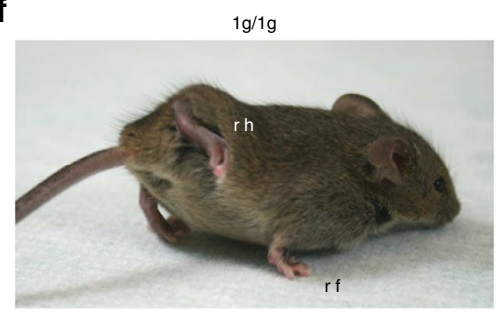

g

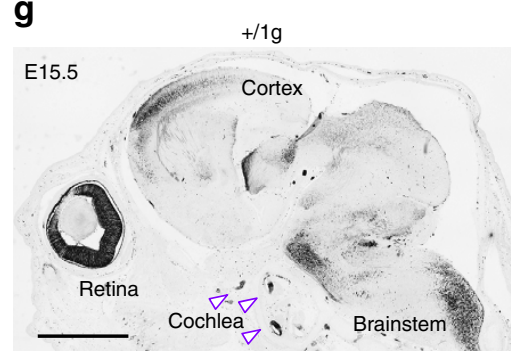

Figure 1 | Differential expression of ROR $\boldsymbol{\beta}$ isoforms and targeted deletion of RORß1. (a) ROR $\beta 1$ and ROR $\beta 2$ mRNA expression profiles in mouse retinal development, determined by qPCR analysis. Levels for each isoform are indicated as percentages relative to the highest level, assigned a value of $100 \%$. (b) Rorb gene with ROR $\beta 1$ - and ROR $\beta 2$-specific exons depicted as black and white boxes, respectively, common exons as grey boxes and ROR $\beta 1$ and ROR 32 promoter regions as triangles. (c) Targeted replacement of the coding portion of the ROR $\beta 1$-specific exon with a gfp cassette that carries a TAA translational stop codon. Excision of the neomycin-resistance ACN cassette left a residual loxP site in the Rorb 19 allele. (d) Loss of ROR 31 mRNA and retention of ROR $\beta 2$ mRNA in brain and retina in $1 \mathrm{~g} / 1 \mathrm{~g}$ mice shown by PCR with control analysis for $\beta$-actin. DNA size marker, bp. (e) Loss of ROR $\beta 1$ protein in the retina in $1 \mathrm{~g} / \mathrm{lg}$ mice shown on a western blot with control analysis for $\beta$-actin. Arrowheads, bands for ROR $\beta 1$ (lower, $\sim 52 \mathrm{kDa}$ ) and ROR $\beta 2$ (upper, $\sim 53 \mathrm{kDa}$ ). The gfp protein expressed in $1 \mathrm{~g} / 1 \mathrm{~g}$ mice carries no ROR $\beta$ protein sequence and was detected with antibody against gfp as a $\sim 27-\mathrm{kDa}$ band (not shown). Protein molecular size marker, kDa. (f) Abnormal gait in 1g/1g mice with exaggerated lifting and clasping of hindlimbs; rh, right hindlimb; rf, right forelimb. (g) Para-sagittal section of $+/ 1$ g embryonic head showing gfp expression in retina, cochlea and brain. Expression of gfp was detected by immunohistochemistry (dark areas). Scale bar, $1 \mathrm{~mm}$. 
identical in their central DNA-binding and C-terminal domains but differ in their $\mathrm{N}$-terminal extensions, consisting of 2 and 13 amino acids, respectively (Fig. 1b). ROR $\beta 1$ and ROR $\beta 2$ are expressed from distinct promoters upstream of their respective $5^{\prime}$-coding exons in the Rorb gene. The gfp cassette was inserted by targeted mutagenesis in embryonic stem cells, which were used to generate mice carrying this Rorb ${ }^{1 g}$ allele (Fig. 1c). Southern blot and genomic sequencing analyses confirmed the structure of the Rorb ${ }^{\text {Ig }}$ allele.

ROR $\beta 1$-specific mRNA was undetectable, whereas ROR $\beta 2$ specific mRNA remained intact in the brain and retina of homozygous Rorb ${ }^{1 \mathrm{~g} / \mathrm{lg}}$ (1g/1g) mice (Fig. 1d). Western blot analyses demonstrated loss of the major ROR $\beta 1$-specific protein band and retention of the minor, ROR $\beta 2$-specific band in the retina of $1 \mathrm{~g} / \mathrm{lg}$ embryos (Fig. 1e). Heterozygous $+/ 1 \mathrm{~g}$ mice showed no overt phenotype but $1 \mathrm{~g} / \mathrm{g}$ mice displayed abnormal gait with exaggerated raising of the hindlimbs similar to that described for $R \mathrm{rb}^{-1-}$ mice lacking all $\operatorname{ROR} \beta$ isoforms ${ }^{26}$, indicating that the ROR $\beta 1$ isoform is critical for hindlimb motor control (Fig. 1f).

Retinal expression pattern of Rorb $^{1 g}$ allele. ROR $\beta 1$ expression was traced in $+/ 1 \mathrm{~g}$ mice, which revealed gfp expression in the embryonic retina as well as in the immature cochlea, brainstem, spinal cord and cerebral cortex, shown at embryonic day 15.5 (E15.5) in Fig. 1g. In the retina, gfp expression displayed a dynamically changing pattern beginning in neuroblastic cells as early as E11.5. Strong gfp signals were detected in the nascent amacrine cell zones in both the inner nuclear layer (INL) and ganglion cell layer during the embryonic and neonatal period when amacrine cells are generated ${ }^{5}$ (Fig. 2a). By postnatal day 7 (P7), gfp was also detected within the inner plexiform synaptic layer in two stratified layers characteristic of the lateral projections of amacrine cells. Developmentally changing but weaker gfp signals were also detected in bipolar neurons, photoreceptors and Muller glia. In general, gfp signals declined after P7 with low levels remaining at older stages, consistent with previous data for Rorb mRNA ${ }^{27,30}$. In the embryonic retina, many gfp ${ }^{+}$cells in the outer neuroblastic layer were positive for proliferating cell nuclear antigen (PCNA), a marker of dividing progenitor cells in G1, S and G2 phases of the cell cycle ${ }^{39}$ (Fig. 2b).

Further analysis co-localized gfp signals with calbindin, a marker of horizontal cells and a sub-population of amacrine cells at late embryonic and neonatal stages (Fig. 2c). At early stages, almost all calbindin ${ }^{+}$horizontal cell precursors were gfppositive. By P1, gfp was also detected in most cells that expressed syntaxin, a marker for all amacrine cell types (Fig. 2d). During later stages of differentiation, gfp signals declined in both calbindin ${ }^{+}$horizontal and syntaxin ${ }^{+}$amacrine cells. Thus, the data indicated that ROR $\beta 1$ was expressed in progenitor cells and subsequently, at enhanced levels in newly generated horizontal and amacrine cell precursors, followed by declining levels during later development.

$\operatorname{Rorb}^{1 g / 1 g}$ mice lack amacrine and horizontal cells. ROR $\beta 1$ deficient mice displayed a collapsed inner plexiform layer, disorganized outer plexiform layer and a thin inner nuclear layer that was only 3 or 4 soma deep compared with $\sim 6$ soma deep in $+/+$ mice (Fig. 3a). These abnormalities reflected loss of horizontal and amacrine cells as demonstrated on retinal flatmounts analysed for calbindin, a marker of both cell classes (Fig. 3b). Ganglion cells were mis-located in the collapsed inner plexiform layer (Fig. 3a) but still formed an optic nerve in $1 \mathrm{~g} / \mathrm{lg}$ mice. Other a

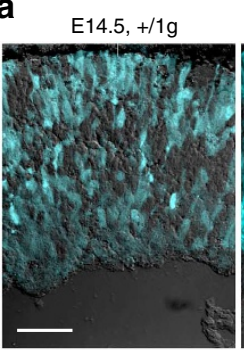

C

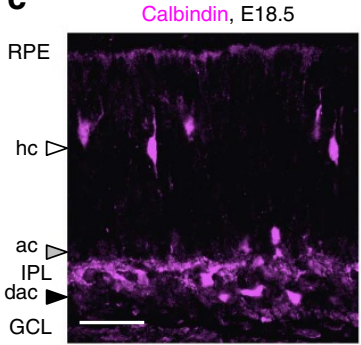

E18.5, +1/g

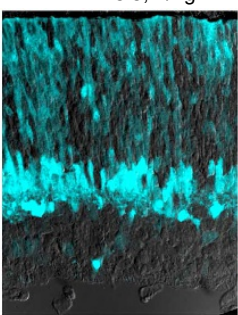

Calbindin, gfp, DIC, E18.5

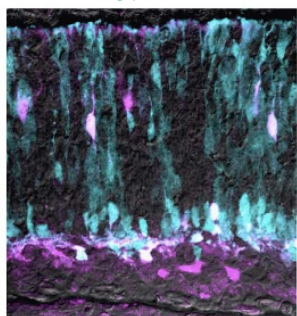

$\mathrm{P} 7,+/ 1 \mathrm{~g}$

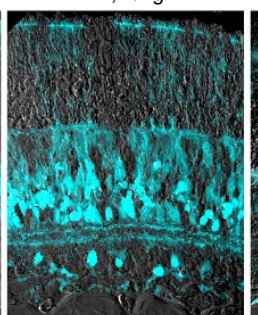

$\mathrm{P} 14,+1 \mathrm{~g}$

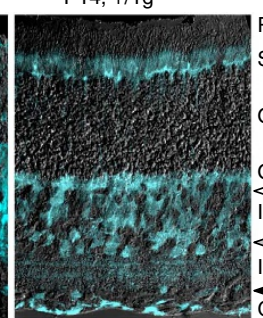

$\mathrm{P} 14,+/+$

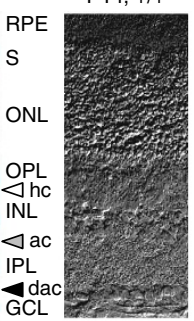

b

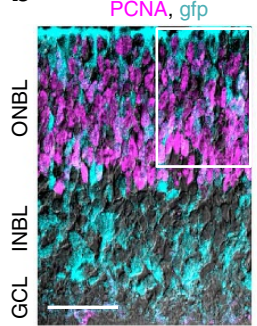

DIC, E15.5

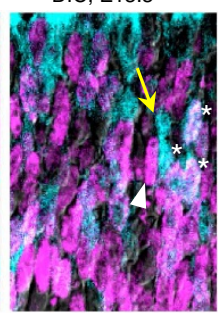

d
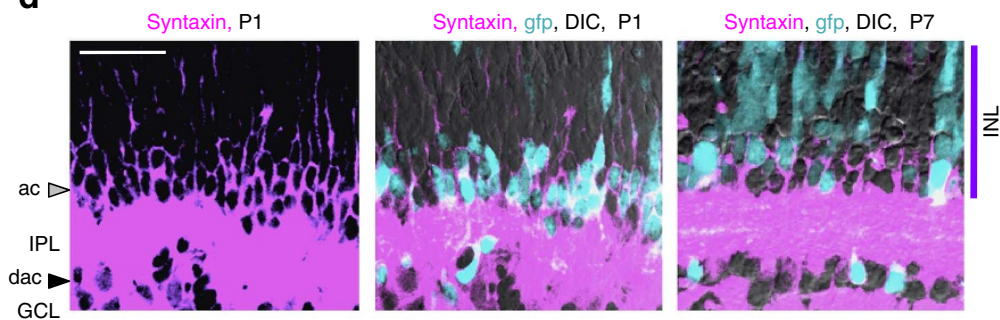

Figure 2 | Expression of $\boldsymbol{R o r b}^{\mathbf{1 g}}$ allele in retina. (a) Developmental analysis in $+/ 1 \mathrm{~g}$ mice showing gfp (turquoise fluorescence) overlaid on differential interference contrast (DIC) images to show cell layers. GCL, ganglion cell layer, INL, inner nuclear layer, IPL, inner plexiform layer, $\mathrm{ONL}$, outer nuclear layer, OPL, outer plexiform layer, RPE, retinal pigmented epithelium, S, inner/outer segment layers. White, grey and black arrowheads indicate horizontal cell (hc), amacrine cell (ac) and displaced amacrine cell (dac) zones, respectively. Control $+/+$ retina shows absence of gfp signal. Scale bar, $30 \mu \mathrm{m}$ in all panels. (b) Detection of proliferative progenitor cells (PCNA, purple) that express gfp (turquoise) overlaid on a DIC image in a $+/ 1 \mathrm{~g}$ embryo. Double detection of gfp and PCNA required $\mathrm{HCl}$ pre-treatment of sections. In the outer neuroblastic layer (ONBL), many cells co-express both PCNA and gfp (white or whitish). Right, enlargement of boxed ONBL area showing PCNA ${ }^{+} /$gfp $^{+}$cells (asterisks), PCNA ${ }^{+}$cells (white arrowhead) and gfp ${ }^{+}$cells (yellow arrow). (c) Rorb ${ }^{1 g}$ expression (turquoise) in immature horizontal, amacrine and displaced amacrine cells identified with calbindin (purple) in a $+/ 1$ g embryo. Co-localization of calbindin and gfp results in whitish cells, overlaid on a DIC image. (d) Rorb ${ }^{1 \mathrm{~g}}$ expression (turquoise, soma) in immature amacrine cells identified with syntaxin (purple, honeycomb pattern around the soma). At P1 (left two panels), most syntaxin ${ }^{+}$cells are gfp ${ }^{+}$ but at P7 (right), fewer are gfp + and many have only weak gfp signals. Amacrine cells form a zone $\sim 3$ soma deep in the INL. 
a

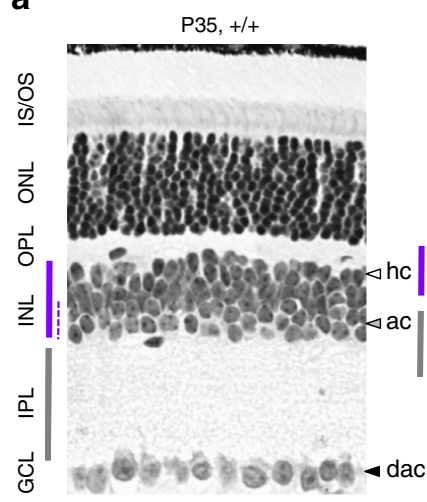

P $35,1 \mathrm{~g} / \mathrm{gg}$

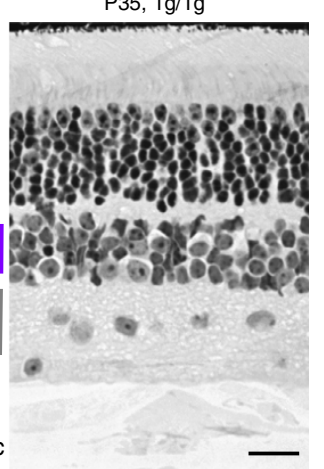

b

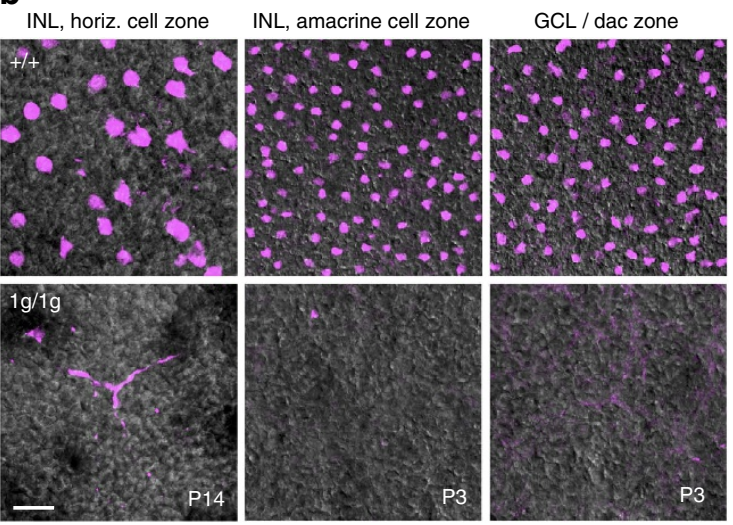

C

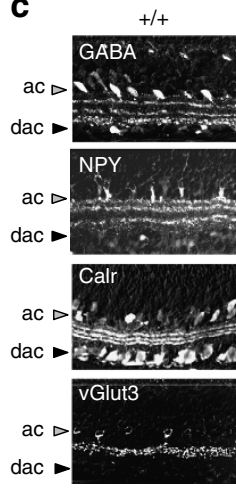

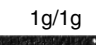

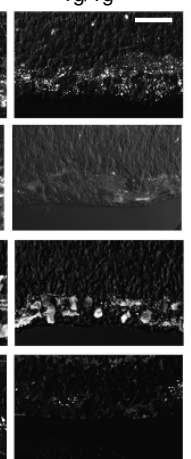

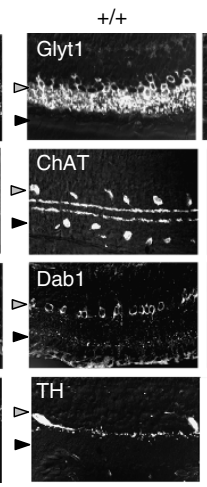

$1 \mathrm{~g} / 1 \mathrm{~g}$

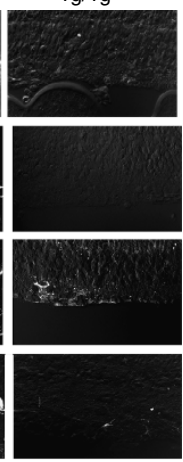

d

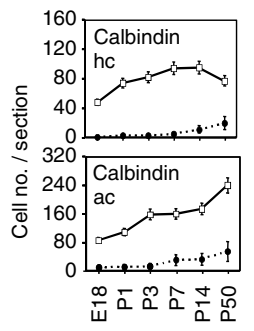

$-t+++\quad \cdots \bullet \cdots 1 \mathrm{~g} / 1 \mathrm{~g}$
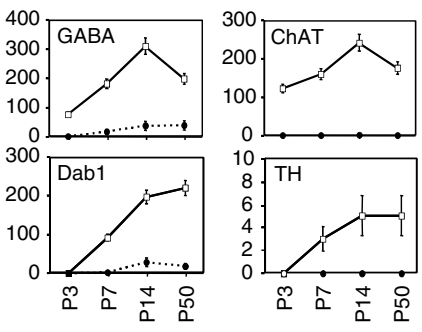

Developmental age (days)

Figure 3 | Loss of amacrine and horizontal cells in Rorb $\mathbf{~}^{\mathbf{g} / \mathbf{1 g}}$ mice. (a) Histological sections showing disorganized inner plexiform, outer plexiform and ganglion cell layers in $\mathrm{lg} / \mathrm{lg}$ mice at P35. Note the thin INL (purple bar) and mis-located ganglion cell soma in the collapsed IPL in $1 \mathrm{~g} / \mathrm{lg}$ mice. Amacrine cell zone in the INL is indicated by a dashed line in $+/+$ retina. Scale bar, $30 \mu \mathrm{m}$ in all panels. (b) Retinal flatmounts analysed by confocal microscopy in the plane of horizontal ( $\mathrm{hc}$ ), amacrine (ac) and displaced amacrine ( $\mathrm{dac}$ ) cell zones using calbindin as a marker (purple) on DIC images to show tissue structure. Calbindin ${ }^{+}$horizontal and amacrine cells are missing in $1 \mathrm{~g} / 1 \mathrm{~g}$ mice. (c) Retinal sections showing loss of representative amacrine cell markers (GABA, GlyT1, neuropeptide Y (NPY), ChAT, calretinin/calr, Dab1, vGlut3, TH) in 1g/1g mice at P14 (except NPY at P7). (d) Cell counts showing failure to generate amacrine and horizontal cells, identified with horizontal (calbindin/hc) and amacrine (calbindin/ac, GABA, ChAT, Dab1, TH) markers. Calbindin ${ }^{+}$ horizontal and amacrine cells were distinguished in $+/+$ mice by morphology and location in the INL. Cell counts, given as mean \pm s.d., were based on analysis of 12 cryosections of the retina representing $\geq 3$ mice at each age.

major classes of retinal cells, including bipolar cells, Muller glia, rods and cones were present as indicated by histology and analysis of cell type markers (Supplementary Fig. S1).

Analysis of retinal sections (Fig. 3c) revealed loss of multiple amacrine cell sub-types in $1 \mathrm{~g} / 1 \mathrm{~g}$ mice as indicated by loss of signals for: (i) $\gamma$-aminobutyric acid (GABA) and neuropeptide $Y$, markers of GABA-ergic cells, (ii) glycine transporter T1 (GlyT1) and disabled 1 (Dab1), markers of glycinergic cells, (iii) vesicular glutamate transporter 3 (vGlut3) a marker of glutamatergic cells, (iv) choline acetyl transferase (ChAT), a marker of cholinergic cells, (v) tyrosine hydroxylase (TH), a marker of dopaminergic cells, and (vi) calretinin (calr), a marker of $\sim 40 \%$ of all amacrine cells of several sub-types. Analysis of pan-amacrine cell markers syntaxin 1 and Pax6 transcription factor confirmed a general depletion of amacrine cell types (Supplementary Fig. S1).

Counts of cells expressing representative amacrine (GABA, Dab1, ChAT, TH, calbindin) and horizontal (calbindin) markers revealed that amacrine and horizontal cells were missing from early stages of development in $1 \mathrm{~g} / 1 \mathrm{~g}$ mice (Fig. $3 \mathrm{~d}$ ), indicative of a developmental failure to generate these cells rather than a later loss by degeneration.

Expression of gfp was maintained in the retina in $1 \mathrm{~g} / \mathrm{g}$ embryos, suggesting that progenitors continued to be generated in the absence of ROR $\beta 1$ (not shown). Indeed, analysis of bromodeoxyuridine (BrdU) incorporation, an indicator of cell proliferation, revealed comparable numbers of $\mathrm{BrdU}^{+}$cells in $+/+$ and $1 \mathrm{~g} / 1 \mathrm{~g}$ mice at E12.5 and P1 (Fig. 4a). Previous studies in Ptfla-deficient mice showed that a lack of amacrine and horizontal cells was accompanied by an excess of ganglion cells, suggesting a possible fate switch for progenitors that normally would form amacrine and horizontal cells ${ }^{10,11}$. We similarly observed $\sim 2$-fold increased $\mathrm{Brn}_{3} \mathrm{a}^{+}$ganglion cell numbers at embryonic and neonatal ages in $1 \mathrm{~g} / 1 \mathrm{~g}$ mice (Fig. $4 \mathrm{~b}, \mathrm{c}$ ). During postnatal development, numbers of $\mathrm{Brn} 3 \mathrm{a}^{+}$cells declined while increased numbers of caspase $3^{+}$cells were detected in $1 \mathrm{~g} / 1 \mathrm{~g}$

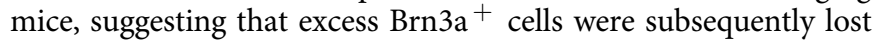
by programmed cell death in $1 \mathrm{~g} / \mathrm{g}$ mice. This phenotype of loss of horizontal and amacrine cells coupled with increased ganglion cell numbers, suggested that ROR $\beta 1$, like Ptf1a, may influence a pathway with alternative differentiation outcomes of ganglion cell versus amacrine and horizontal cells ${ }^{10,11}$.

Loss of transcription factor expression in $\operatorname{Rorb}^{1 g / 1 g}$ mice. The developmental stage at which ROR $\beta 1$ acts relative to Foxn4, Ptfla and other transcription factors involved in amacrine and horizontal cell differentiation was investigated. In situ hybridization detected the presence of Foxn 4 but loss of Ptfla mRNA in $1 \mathrm{~g} / 1 \mathrm{~g}$ 

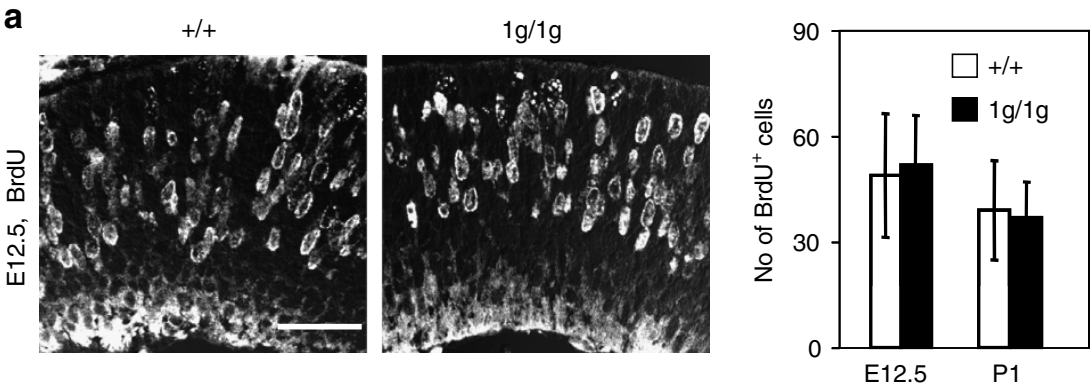

b
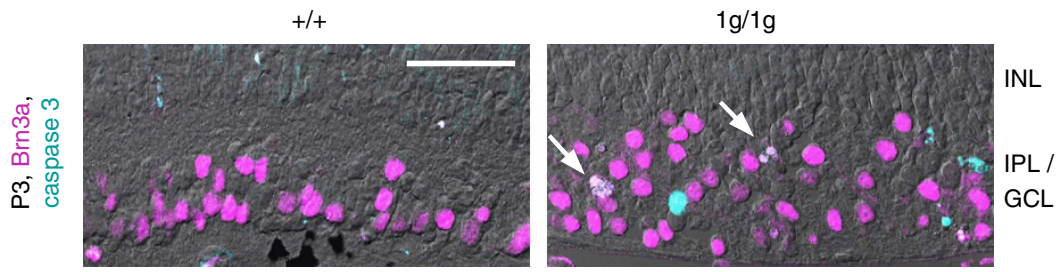

C
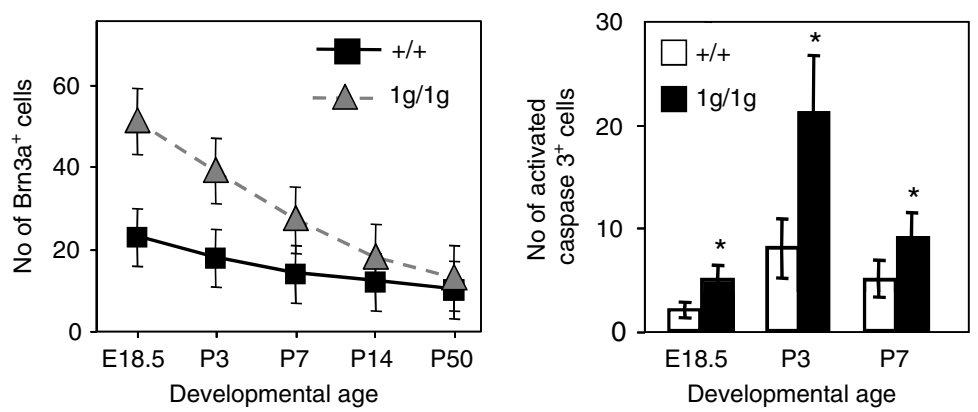

Figure 4 | Excess ganglion cells in Rorb ${ }^{\mathbf{1 g}} / \mathbf{1 g}$ mice. (a) Normal numbers of BrdU ${ }^{+}$proliferating cells were detected in the retina in $1 \mathrm{~g} / 1 \mathrm{~g}$ mice $1 \mathrm{~h}$ after a pulse delivery of BrdU. Graph of BrdU ${ }^{+}$cell counts at E12.5 and P1 shows no differences between $+/+$and $1 \mathrm{~g} / \mathrm{lg}$ mice; mean \pm s.d.; $P>0.8$. Counts represent BrdU ${ }^{+}$cells per $150 \mu \mathrm{m}$ length of retina, determined on $10 \mu \mathrm{m}$ thick cryosections. Scale bar, $30 \mu \mathrm{m}$ in all panels. (b) Immunostaining for Brn3a ${ }^{+}$ ganglion cells (purple) in retinal sections at P3. Sections were co-stained for activated caspase 3 (turquoise), a marker of apoptotic cells. Arrows, doublelabelled cells in 1g/1g mice, which were rarely observed in $+/+$ mice. (c) The postnatal decline in excess Brn3a ${ }^{+}$cells correlated with increased cell death rates in $1 \mathrm{~g} / \mathrm{lg}$ mice. Left, counts of Brn3a ${ }^{+}$cells per $150 \mu \mathrm{m}$ length of retina in $10 \mu \mathrm{m}$ thick sections. For $+/+$ and $1 \mathrm{~g} / 1 \mathrm{~g}$ differences at E18.5, P3 and $P 7, P<0.001$. Right, counts of caspase $3^{+}$cells per section; mean \pm s.d.; ${ }^{\star} P<0.001$. Statistical analyses were performed using Student's $t$-test.

mice at E15.5 (Fig. 5a). Quantitative PCR (qPCR) analysis demonstrated a normal developmental profile for Foxn4 mRNA levels, whereas Ptfla mRNA was lacking from early stages in 1g/ $1 \mathrm{~g}$ mice (Fig. 5b). Previously, a partial loss of $\mathrm{Nd} 1$ and $\mathrm{Nd} 4$ mRNA was reported in Foxn $4^{-l-}$ mice at $\mathrm{E} 15^{9,32}$. In situ hybridization revealed a moderate reduction of $\mathrm{Nd} 1$ and $\mathrm{Nd} 4$ mRNA signals in $1 \mathrm{~g} / 1 \mathrm{~g}$ embryos (Fig. 5a) and $\mathrm{qPCR}$ revealed $37 \pm 5$ and $45 \pm 8 \%(P<0.001)$ decreases of $\mathrm{Nd} 1$ and $\mathrm{Nd} 4$ mRNA levels, respectively, in $1 \mathrm{~g} / 1 \mathrm{~g}$ embryos at E14.5 (Supplementary Fig. S2).

Loss or reduced expression of transcription factors that influence specifically horizontal (Prox1, Lim1) or amacrine (Nr4a2, bHLHb5, Ebf3) sub-lineage differentiation was also detected in $1 \mathrm{~g} / \mathrm{g}$ mice by in situ hybridization, immunohistochemical and qPCR analyses (Fig. 5a) (Supplementary Fig. S2). These data suggested that ROR $\beta 1$ acts upstream of Ptfla but in parallel with Foxn 4 at early stages of amacrine and horizontal cell differentiation.

The Ptfla gene contains an RORß1-responsive enhancer. The mechanism of regulation of Ptfla expression in the retina is unknown. Thus, loss of Ptf1a expression in $1 \mathrm{~g} / 1 \mathrm{~g}$ mice suggested the hypothesis that ROR $\beta 1$ induces the Ptfla gene. Given that Foxn $4^{-1-}$ mice similarly lacked Ptfla expression ${ }^{10}$, we also tested whether ROR $\beta 1$ and Foxn4 cooperatively induced Ptf1a. Previous studies identified a 2.2-kb upstream region and a 12.4$\mathrm{kb}$ downstream region of the Ptfla gene that directed reporter transgene expression in the spinal cord, hindbrain, pancreas and retina in mice ${ }^{33,34}$. We tested conserved fragments from these regions for enhancer function in response to ROR $\beta 1$ and Foxn4 using a luciferase reporter with a $0.6-\mathrm{kb}$ Ptfla promoter region (Fig. 6a). When transfected into $293 \mathrm{~T}$ cells, a 1.6-kb downstream fragment, or a $0.8-\mathrm{kb}$ sub-domain of this fragment (En0.8), conferred a remarkable $\geq 90$ fold synergistic activation of the reporter in the presence of both ROR $\beta 1$ and Foxn 4 when normalized over basal expression in the absence of added factors $(P<0.001)$. In contrast, ROR $\beta 1$ and Foxn 4 individually gave only 3.3-fold and 5.1-fold activation, respectively (Fig. 6c,d) (difference for both factors compared with ROR $\beta 1$ alone $P<0.001$, or Foxn4 alone $P<0.001)$. In comparison, other enhancer fragments tested, including the upstream $2.2 \mathrm{~kb}$ fragment $(\operatorname{Pr} / \mathrm{En} 2.2)$ gave relatively little change in the response to both factors compared with the promoter alone reporter.

The $0.8 \mathrm{~kb}$ sub-fragment contained a candidate ROR $\beta 1$ response element (RORE, 5'-AAACTAGGTTA- $3^{\prime}$ ) related to the $5^{\prime}-(\mathrm{A} / \mathrm{T})_{\mathrm{n}} \mathrm{NAGGTCA}-3^{\prime}$ consensus ${ }^{29,27}$ (Fig. 6b,e). This RORE was $100 \%$ conserved and the surrounding $760 \mathrm{bp}$ sequence was $75 \%$ conserved between human and mouse genomes. Mutagenesis of the RORE in the context of En0.8 
a
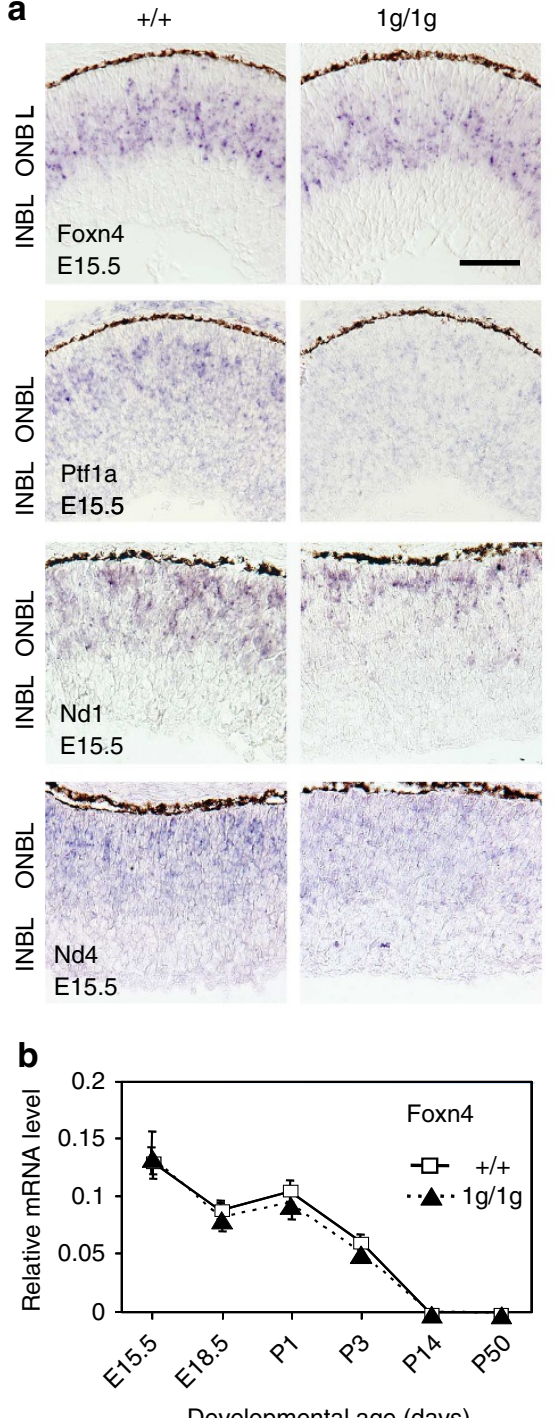
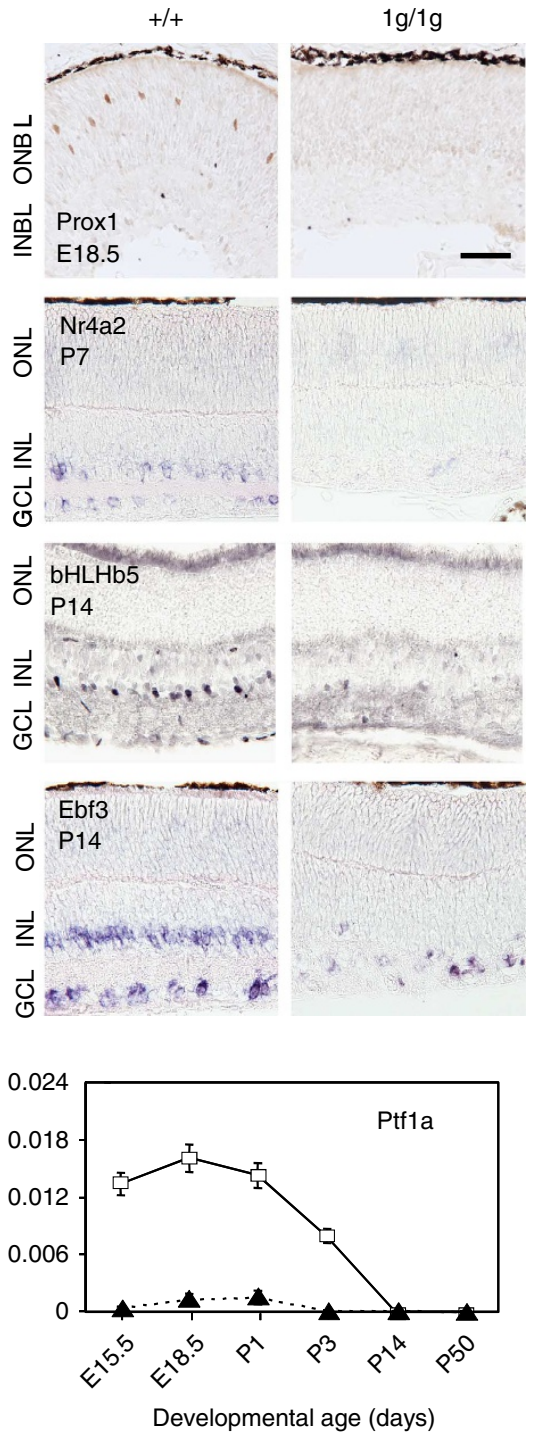

Figure 5 | Expression of retinal transcription factors in $\mathbf{R o r b}^{\mathbf{1 g} / \mathbf{1 g}}$ mice. (a) Transcription factor expression analysed by in situ hybridization (Foxn4, Ptf1a, Nd1, Nd4, Nr4a2, Ebf3) or immunohistochemistry (Prox1, bHLHb5), at stages when each factor normally displays prominent expression (early stages, left, or later maturation stages, right). Ptfla was overtly and $\mathrm{Nd} 1$ and $\mathrm{Nd} 4$ were modestly reduced in $1 \mathrm{~g} / \mathrm{lg}$ mice. Expression of horizontal (Prox1) and amacrine sub-lineage (Nr4a2, bHLHb5, Ebf3) markers was severely reduced in $1 \mathrm{~g} / \mathrm{lg}$ mice. Scale bar, $30 \mu \mathrm{m}$. (b) qPCR analysis demonstrating normal Foxn4 but reduced Ptfla mRNA levels in Rorb ${ }^{1 g / 1 g}$ mice during development. Each point represents mean of three analyses on pooled retina ( $>4$ mice) at each age. Plots based on mean \pm s.d. at each age.

impaired both the individual response to $\mathrm{ROR} \beta 1$ and the synergistic response to ROR $\beta 1$ and Foxn4 (each $P<0.001$ compared with wild-type $\operatorname{Pr} / \mathrm{En} 0.8$ ) (Fig. 6c,d). A control mutation $345 \mathrm{bp}$ distant from the RORE interfered minimally with responses to ROR $\beta 1$ and Foxn4 (not shown). En0.8 also contained two putative elements for Foxn factors based on a core ACGC motif ${ }^{32,35}$, located $185 \mathrm{bp}$ upstream (F1) and $125 \mathrm{bp}$ downstream (F2) of the RORE (Fig. 6b,e). Of two candidate ACGC motifs in F1, the downstream site and flanking bases were conserved in mouse and human genomes, whereas in F2, the most upstream of two candidate motifs was conserved. Individual mutagenesis of ACGC motifs in F1 and in F2 partly reduced the synergistic response to ROR $\beta 1$ and Foxn4 $(P<0.001)$, whereas combined mutagenesis of RORE, F1 and F2 more severely diminished the response $(P<0.001)$ (Fig. 6c).

Direct regulation of the Ptfla gene by ROR $\beta 1$ and Foxn 4 was suggested by DNA-binding studies. In an electrophoretic mobility shift assay (EMSA), an oligonucleotide probe representing the RORE in the En 0.8 enhancer bound ROR $\beta 1$ protein obtained by overexpression in $293 \mathrm{~T}$ cells (Fig. 6f). The shifted band was diminished by addition of excess wild-type but not mutant competitor oligonucleotides. The shifted band was also supershifted by addition of antibody against ROR $\beta$ but not by a control immunoglobulin. Also, probes containing the conserved ACGC sequences in F1 and F2 each bound Foxn4 protein in EMSA (Fig. 6g). The specific shifted band for each probe was diminished strongly by wild-type but weakly by mutant competitor oligonucleotides.

Although the molecular basis of the synergy between ROR $\beta 1$ and Foxn 4 remains unclear, the possibility that ROR $\beta 1$ and Foxn 4 interact physically was investigated by protein pull-down analyses using extracts from $293 \mathrm{~T}$ cells that overexpress ROR $\beta 1$ $(\beta 1)$ and histidine-tagged Foxn4 (H.F4) (Fig. 6h). Isolation of tagged Foxn4 by nickel-chelate chromatography co-selected 
a

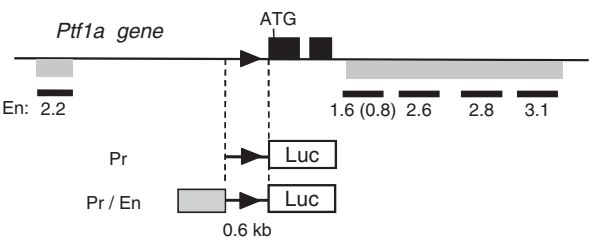

b

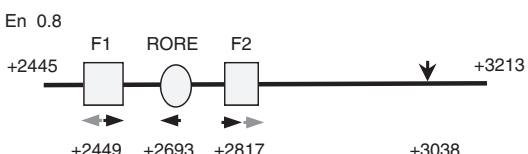

e

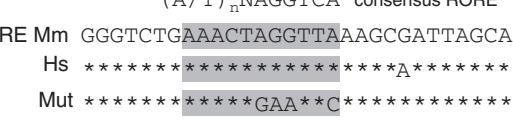

F1 Mm GGCAGGAGACGCTCTCTTTGGCGT
Hs $* \mathrm{~A} * \mathrm{~T} * * * * * * * * \mathrm{G} * * * \mathrm{~A} * * * \mathrm{~A} * * *$
Mut $* * * * * * * * \mathrm{CA}^{* *} * * * * * * * * * * * *$

F2 Mm CTGGCCAGACACGCTGAGATTCTG $\mathrm{HS} * * * * * * * * * * * * * * \mathrm{G} * * * * * * * * *$ Mut $* * * * * * * * * * \overline{G G A T} * * * * * * * * * *$
C

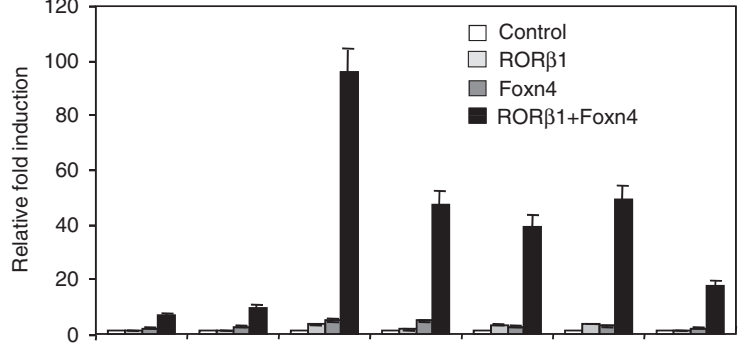

d

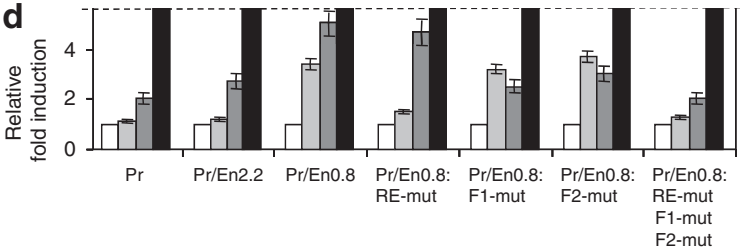

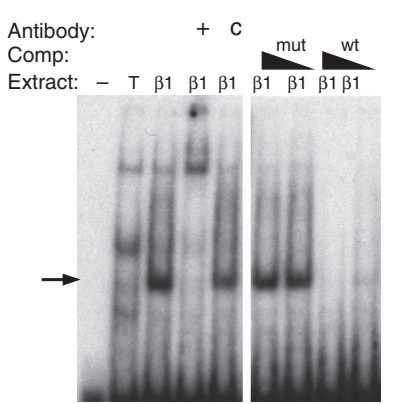

RORE probe
9

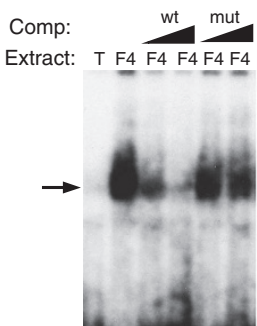

F1 probe

Figure 6 | RORß1-responsive enhancer in Ptf1a gene. (a) Ptf1a gene; black boxes, exons; triangle, promoter; grey bars below gene, enhancer regions. Enhancer (En) fragments tested are shown as black bars with size (kb) below. Reporter constructs contained a 0.6-kb Ptfla promoter driving luciferase without ( $\mathrm{Pr}$ ) or with enhancer fragments ( $\mathrm{Pr} / \mathrm{En}$ ). (b) Foxn4 (F1, F2) and RORß1 (RORE) response elements in En0.8 fragment. Arrowheads, motifs and orientation; black arrowheads, conserved between mouse and human genomes. Numbers, distances (in bp) from ATG. Vertical arrow ( + 3038) indicates a distant control mutation. (c) Luciferase assays in 293T cells for reporter responses to ROR $\beta 1$ and Foxn4 normalized to basal expression of each reporter in absence of added factors; means \pm s.d. $\mathrm{Pr} / \mathrm{En} 0.8$ gave $>10$-fold greater synergistic induction than $\operatorname{Pr}$ promoter alone $(P<0.001)$. Fold induction of $\mathrm{Pr} /$ En0.8 by both factors together (black columns) was reduced by individual or combined mutagenesis (mut) of RORE, F1 and F2 sites ( $P<0.001$ for each mutant compared with wild-type). Statistical analyses were performed using Student's t-test. (d) Magnification of lower region of response scale in panel ' $c$ '. Note: responses to both factors (black columns) are truncated above the dashed line. (e) RORE, F1 and F2 sequences in mouse (Mm) and human (Hs) genomes; asterisks indicate identity; core motifs shaded. Mouse wild-type and mutant (mut) sequences were used as EMSA probes. (f) EMSA of RORB1 binding to RORE using extracts from 293T cells transfected with ROR $\beta 1$-expressing ( $\beta 1$ ) or empty $(T)$ vector; probe alone ( - ). Competition with wild-type (wt) but not mutant (mut) unlabelled oligonucleotides abolished the shifted band (arrow). Anti-ROR $\beta$ antibody ( + ) but not lgG control (c) supershifted the band. (g) EMSA of Foxn4 binding to F1 and F2 using extracts from 293T cells transfected with Foxn4-expressing (F4) or empty (T) vector. Competition with wild-type but not mutant oligonucleotides strongly diminished the shifted band (arrow). (h) Protein interaction between ROR 31 and Foxn4. Left, input protein from 293 T cells transfected with empty vector (vec), or vectors expressing histidine-tagged Foxn4 (H.F4), ROR $\beta 1$ ( $\beta 1)$ or both (H.F4 + $\beta 1)$ analysed by western blot (ROR $\beta$, upper; Foxn4, lower). Right, Nickel-chelate selection for H.F4 protein co-selected a weak RORß1 band. Protein molecular size marker, kDa.

ROR $\beta 1$, which was identified by western blot analysis. The coselected ROR $\beta 1$ band was specific but relatively weak. However, in EMSA, the addition of both Foxn 4 and ROR $\beta 1$ did not alter the migration of the RORE probe compared with the shift given by ROR $\beta 1$ alone, indicating that the RORE site did not represent a composite element that bound a dimeric ROR $\beta 1 /$ Foxn 4 protein complex (not shown). A reciprocal experiment also indicated that $\mathrm{F} 1$ or $\mathrm{F} 2$ probes did not represent composite DNA-binding sites for ROR $\beta 1 /$ Foxn 4 complexes. The evidence suggests that ROR $\beta 1$ and Foxn 4 primarily bind to their respective DNA elements in the Ptfla gene and only secondarily contact each other.
RORB1 promotes amacrine cell generation. To determine if ROR $\beta 1$ stimulates differentiation in a gain-of-function experiment, a vector expressing ROR $\beta 1$ from a constitutively active ubiquitin promoter (Ub/ROR $\beta 1$ ) was electroporated into the retina of neonatal (P0) mice ${ }^{36}$ (Fig. 7). A co-electroporated plasmid expressing Td tomato (TdT) allowed identification of electroporated cells. Differentiation outcomes were analysed at P14, when amacrine and horizontal cell populations normally have been formed and can be identified by their morphology and location in the retinal layers.

Compared with Ub/empty vector, Ub/ROR $\beta 1$ electroporated into $+/+$ mice of the CD1 strain yielded large numbers of 
a
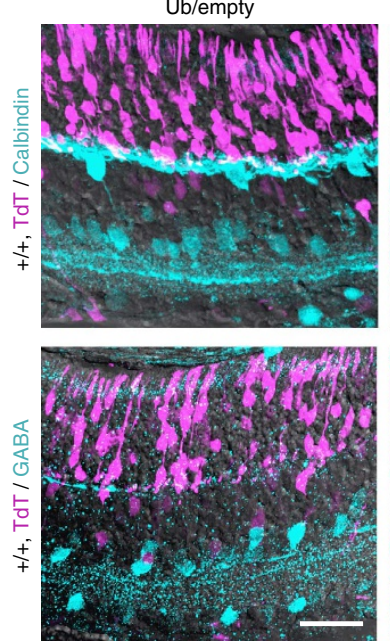

Ub/ROR $\beta 1$

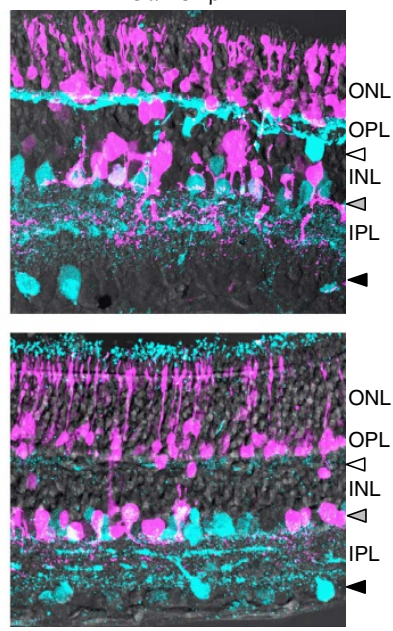

b
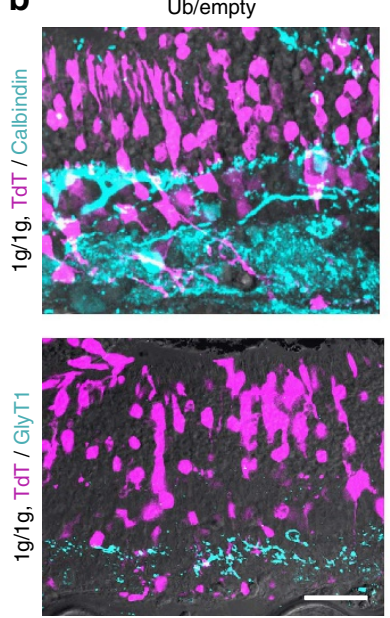

$\mathrm{Ub} / \mathrm{ROR} \beta 1$
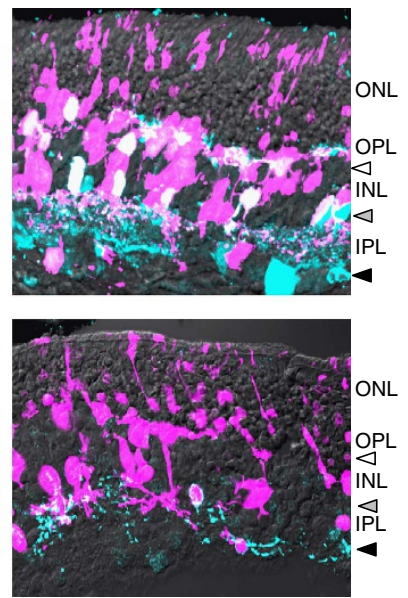

C

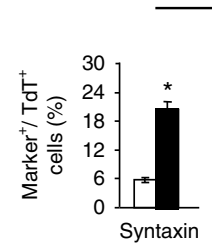

$+/+$
$1 \mathrm{~g} / 1 \mathrm{~g}$
$++$
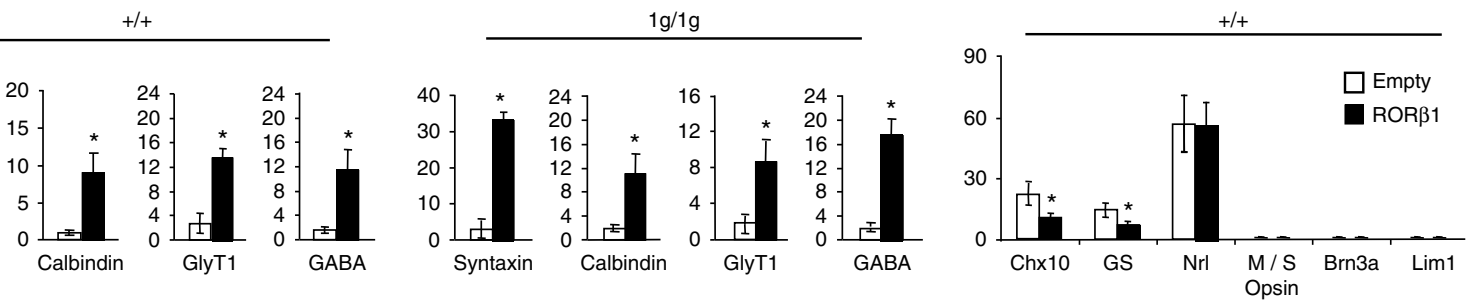

Figure 7 | RORß1 promotes amacrine cell differentiation. (a) Retinal sections of $+/+$ mice at P14 after electroporation at PO with Ub/empty control or Ub/RORB1-expression vector. Electroporated cells were identified by co-electroporated TdT marker. TdT ${ }^{+}$(purple), calbindin ${ }^{+}$or GABA ${ }^{+}$amacrine cells (turquoise) and double-positive cells (white/whitish) were visualized by confocal imaging. Horizontal, amacrine and displaced amacrine cell zones are indicated by white, grey and black arrowheads, respectively. Ub/ROR $\beta 1$ yielded many $\mathrm{TdT}^{+}$amacrine cells with projections in the inner plexiform layer. Scale bar, $30 \mu \mathrm{m}$ in all panels. (b) In ROR $\beta 1$-deficient $(1 \mathrm{~g} / \mathrm{lg})$ pups electroporated at PO and analysed at P14, Ub/ROR $\beta 1$ yielded many TdT ${ }^{+}$amacrine-like cells in the INL with projections in the inner plexiform layer. $\mathrm{TdT}^{+}{ }^{+}$, calbindin ${ }^{+}$cells with unusual projections in the outer plexiform layer may be mislocated amacrine cells in the disorganized INL of $1 \mathrm{~g} / \mathrm{lg}$ mice. (c) Counts of cells positive for amacrine (syntaxin, GABA, GlyT1) and combined amacrine/ horizontal (calbindin) markers in $+/+$ (left) and $1 \mathrm{~g} / \mathrm{lg}$ (middle) mice. Counts represent marker ${ }^{+} / \mathrm{TdT}^{+}$electroporated cells in $150 \mu \mathrm{m}$ lengths of retina. Right, counts in $+/+$ mice of cells positive for TdT and bipolar (Chx10), Muller glial (glutamine synthetase, GS), rod (Nrl), cone (M and S opsin), ganglion (Brn3a) or horizontal (Lim1) cell markers. Means \pm s.d.; $\geq 6$ eyes from $\geq 6$ mice; ${ }^{\star} P<0.001$. Statistical analyses were performed using Student's $t$-test.

$\mathrm{TdT}^{+}$cells in the amacrine cell zone of the INL with projections typical of amacrine cells in the inner plexiform layer. Many of these $\mathrm{TdT}^{+}$cells also expressed markers for amacrine cell types (GABA, calbindin, GlyT1, syntaxin) (Fig. 7a,c). However, Ub/ ROR $\beta 1$ yielded few detectable cells in the location of horizontal cells or displaced amacrine cells, probably reflecting limited competence of progenitor cells at the neonatal stage to form some cell types because horizontal cells and a large proportion of amacrine cells have normally been formed by $\mathrm{P}^{3,5}$.

Apart from increased amacrine cell numbers, Ub/ROR $\beta 1$ gave diminished numbers of $\mathrm{Chx} 10^{+}$bipolar cells and glutamine synthetase $^{+}$Müller glial cells compared with Ub/empty vector (Fig. 7c), suggesting that ectopic expression of ROR $\beta 1$ may inhibit progenitors at P0 from acquiring certain cell fates. Analysis of markers for rods ( $\mathrm{Nrl})$, cones ( $\mathrm{M}$ and $\mathrm{S}$ opsin), ganglion cells (Brn3a) and horizontal cells (Lim1) revealed no differences in response to $\mathrm{Ub} / \mathrm{ROR} \beta 1$ or Ub/empty vector. The lack of cells positive for cone, ganglion and horizontal cell markers was consistent with restricted competence of progenitors at P0 to form certain cell types. In summary, ectopic expression of ROR $\beta 1$ at P0 stimulated amacrine cell differentiation and partly suppressed bipolar and Müller glial cell outcomes.

We also investigated whether ROR $\beta 1$ can rescue amacrine and horizontal cell differentiation in neonatal ROR $\beta 1$-deficient mice (Fig. 7b,c). Compared with Ub/empty vector, Ub/ROR $\beta 1$ yielded many $\mathrm{TdT}^{+}$amacrine-like cells, including syntaxin ${ }^{+}, \mathrm{GABA}^{+}$, $\mathrm{GlyT}^{+}{ }^{+}$and calbindin ${ }^{+}$cells in the INL with projections in the inner plexiform layer in $1 \mathrm{~g} / \mathrm{g}$ mice. Ub/ROR $\beta 1$ also produced $\mathrm{TdT}^{+} /$calbindin ${ }^{+}$cells at the outer zone of the INL with lateral projections in the outer plexiform layer. Although these cells resided in the location of horizontal cells, they probably represented amacrine cells that had failed to align in the amacrine cell zones in the disorganized INL in $1 \mathrm{~g} / 1 \mathrm{~g}$ mice, as horizontal cells are normally produced only during embryogenesis ${ }^{4}$. We also detected GABA, an amacrine cell marker, in $\mathrm{TdT}^{+}$cells at this location (not shown). In summary, ectopic overexpression studies indicate that ROR $\beta 1$ promotes amacrine cell but not horizontal cell differentiation in $+/+$ or $1 \mathrm{~g} / \mathrm{lg}$ mice at $\mathrm{P} 0$.

\section{Discussion}

This study indicates that ROR $\beta 1$ is critical for the differentiation of amacrine and horizontal cells and for the transcriptional induction of Ptfla, a necessary factor for the generation of both of these classes of interneurons. The synergistic activation of the Ptfla gene by ROR $\beta 1$ with Foxn4 suggests that a novel cooperation between an orphan nuclear receptor and a forkhead box factor directs a transcriptional pathway for amacrine and horizontal cell differentiation. 


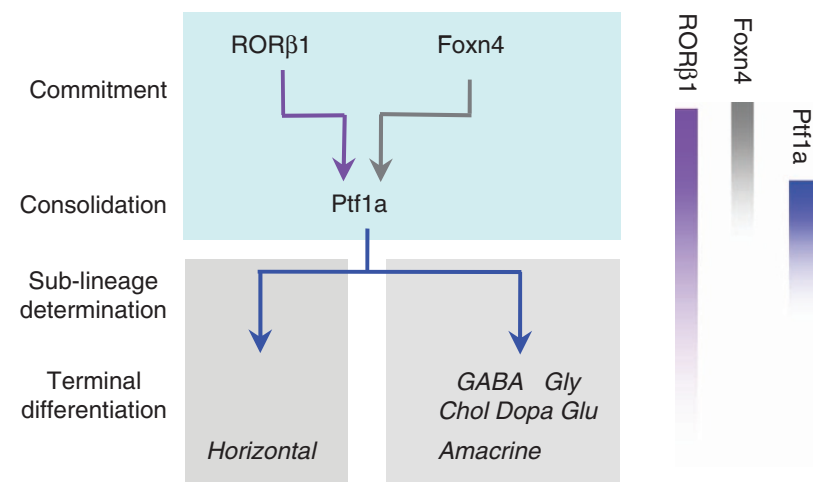

Figure 8 | Proposed role for RORß1 in amacrine and horizontal cell

differentiation. It is proposed that ROR $\beta 1$ and Foxn4 in progenitor cells cooperatively promote commitment to amacrine and horizontal cell fates by synergistic induction of Ptfla. Ptfla is transiently induced in post-mitotic precursors and consolidates the fates of both classes of interneurons. Many factors (not shown) contribute to the subsequent terminal differentiation of horizontal and amacrine cell sub-lineages, indicated here according to main neurotransmitter types (GABA, glycine, acetyl choline, dopamine, glutamate). Relative timing of expression of ROR $\beta 1$, Foxn4 and Ptf1a is indicated on the right: Foxn4 is in dividing progenitors, Ptfla in post-mitotic precursors and ROR $\beta 1$ in both progenitors and precursors.

We propose a model in which ROR $\beta 1$ and Foxn 4 cooperatively prompt progenitors to commit to form precursors for horizontal and amacrine cell types (Fig. 8). A requirement for two factors, rather than only one, may impose stringent selection over which progenitors make this commitment. Consequently, only the requisite cell population may become committed while adequate pools of progenitors are retained for the generation of other retinal cell types. Foxn4 is restricted to dividing progenitors ${ }^{9}$ such that the immediate result of ROR $\beta 1$ and Foxn 4 cooperation may be induction of Ptfla which is transiently expressed in postmitotic precursor cells for both classes of interneurons ${ }^{10,11}$. In accord with this early role for ROR $\beta 1$, Rorb ${ }^{1 \mathrm{~g} / 1 \mathrm{~g}}$ mice have reduced expression of many later-acting transcription factors involved in terminal differentiation of horizontal and amacrine cell sub-lineages. Unlike Foxn4, ROR $\beta 1$ continues to be expressed in post-mitotic horizontal and amacrine cells and may possibly also contribute to later maturational events.

Deficiency of either ROR $\beta 1$ or Foxn $4^{9}$ results in a partial reduction of expression of $\mathrm{Nd} 1$ and $\mathrm{Nd} 4$, which are required for amacrine but not horizontal cell differentiation ${ }^{15}$. Thus, ROR $\beta 1$ and Foxn4 may reside upstream of $\mathrm{Nd} 1$ and $\mathrm{Nd} 4$, although quantification of $\mathrm{Nd} 1$ and $\mathrm{Nd} 4$ expression in the pertinent cells is difficult to accomplish as these factors are expressed in many retinal cell types in developmentally changing patterns. Conceivably, in amacrine cell differentiation, $\mathrm{Nd} 1$ and $\mathrm{Nd} 4$ act upstream of, or in parallel with, Ptfla because $\mathrm{Nd} 1$ and $\mathrm{Nd} 4$ expression is unperturbed in Ptfla ${ }^{-1-}$ mice $e^{10,11}$.

A given transcription factor gene may control diverse neurodevelopmental functions although the basis for this versatility is often unclear. Our evidence indicates that for Rorb, such versatility is facilitated by two properties: first, the ability of ROR $\beta$ proteins to cooperate with other cell-specific factors, such as Foxn4, and second, the ability of the gene to express distinct ROR $\beta 1$ and ROR $\beta 2$ isoforms in cell-specific patterns.

ROR $\beta$ isoforms possess specific DNA-binding properties but only weak trans-activating functions, such that cooperation with other activators in different cell types can allow the induction of specific target genes. Cooperation between ROR $\beta 1$ and Foxn 4 produces a potent synergistic induction of Ptfla expression.
Although the mechanism is unclear at present, the evidence indicates that ROR $\beta 1$ and Foxn 4 each bind to distinct sites within a 350-bp enhancer region in the Ptfla gene. Potentially, the coordinated binding of both factors leads to recruitment of other co-activators or chromatin-activating complexes that stimulate the promoter of the gene. ROR $\beta$ isoforms also cooperate with $\mathrm{Crx}$ homeodomain factor to induce the Opn1sw opsin gene in $\operatorname{cones}^{27}$ and probably also with Otx2 homeodomain factor to induce the $\mathrm{Nrl}$ gene in rods ${ }^{28,37,38}$. In each case, DNA-binding sites exist for both the ROR $\beta$ isoform and its cooperating factor suggesting that DNA binding by both factors is required for transcriptional enhancement. Cooperative interactions have also been suggested to allow regulation of the activity of orphan receptors that lack known physiological ligands. For example, DNA-binding activity by Drosophila Ftzf1 nuclear receptor is regulated by interaction with a homeodomain protein ${ }^{39}$.

The differential expression of $\mathrm{N}$-terminal variant isoforms provides a precise means by which a nuclear receptor gene can direct distinct cellular functions. Thus, ROR $\beta 1$ mediates differentiation of amacrine and horizontal cells and also control of hindlimb movement. The function of the ROR $\beta 2$ isoform is currently undefined but the contrasting expression profiles of ROR $\beta 1$ and ROR $\beta 2$, and the differing phenotypes of mice deleted for $R O R \beta 1$ or all ROR $\beta$ isoforms, implicate ROR $\beta 2$ in photoreceptor differentiation ${ }^{26-28}$. Highly specialized, cellspecific functions have also been described for isoforms encoded by the retinoid-related orphan receptor $\gamma$ (Rorg) and thyroid hormone receptor $\beta$ (Thrb) genes. The ROR $\gamma \mathrm{t}$ isoform encoded by Rorg serves critical functions in inflammatory lymphoid cells ${ }^{40}$, whereas the TR $\beta 2$ isoform encoded by Thrb controls a key step in the differentiation of cone photoreceptors ${ }^{41}$.

\section{Materials and methods}

Targeted mutagenesis and retinal electroporation. $\operatorname{ROR} \beta 1$ and $\operatorname{ROR} \beta 2$-specific exons were identified by alignment of mouse genomic and cDNA sequences (accession nos. NM_001043354, NM_146095). Genomic Rorb 5' and $3^{\prime}$ homology arms isolated from ES cell DNA using Phusion polymerase (NewEngland Biolabs) were inserted into a pACN vector carrying a self-excisable neomycin-resistance gene $(t A C E-C r e-N e o)^{42}$. An enhanced gfp cDNA replaced the ROR $\beta 1$-specific exon. Targeted W9.5 ES cell clones were used to generate chimeric mice by K. Kelley at the Genetics Core Facility, Mount Sinai School of Medicine. Chimeras were crossed with $\mathrm{C} 57 \mathrm{BL} / 6 \mathrm{~J}$ mice, then $R_{0 r}{ }^{+/ 1 g}$ mice intercrossed to generate $+/+,+/ 1 \mathrm{~g}$ and $1 \mathrm{~g} / \mathrm{lg}$ progeny on a C57BL/6J x 129/Sv background for analysis. The ACN cassette self-excised during germline transmission from male chimeras to yield the Rorb ${ }^{1 \mathrm{~g}}$ allele. Genotypes were determined by Southern blot or PCR using as primers: common reverse $5^{\prime}$-GCCTCTTCTACCCAAAGTCAC- $3^{\prime}$, wild-type forward $5^{\prime}$-TCATGCGAGGTAAGCGAGC-3', mutant forward $5^{\prime}$-CAACTA CAACAGCCACAACG-3' ${ }^{\prime}$, yielding wild-type and mutant bands of 358 and $653 \mathrm{bp}$, respectively. In vivo electroporation was performed as described ${ }^{36}$ in wild-type CD1 or Rorb $1^{\mathrm{g} / \mathrm{lg}}$ pups on the mixed background noted above. ROR $\beta 1$ and Foxn 4 cDNAs were inserted into a Ub expression vector ${ }^{43}$. Animal experiments were performed in accordance with protocols approved by the Animal Care and Use Committee at NIDDK and NEI at the National Institutes of Health.

qPCR and western blot analysis. RNA from pooled retinas ( $>4$ mice per pool) was subjected to reverse transcription and real-time qPCR with normalization to $\beta$-actin mRNA levels ${ }^{28}$ using primers for Foxn4, Ptfla, Nd1 Nd4, Lim1, Brn3b, Barhl2, Ebf3, bHLHb5 and Nr4a2 (Supplementary Table S2). Developmental analysis of ROR $\beta 1$ and ROR $\beta 2$ mRNA levels (Fig. 1a) was determined in triplicate on retinal RNA samples pooled from $>3$ mice at each age using primers as follows: $\beta 1 \mathrm{~F}, 5^{\prime}$-CCATCAGAAACAGTCATCAGCAAC- $3^{\prime}, \beta 1 \mathrm{R} 5^{\prime}$-TGGGCAGGAGTAA GAGGCATTG- $3^{\prime}, \beta 2 \mathrm{~F}, 5^{\prime}$-CCGTCAGAATGTGTGAGAACCAG-3 ${ }^{\prime}, \beta 2 \mathrm{R} 5^{\prime}$-ATC CTCCCGAACTTTACAGCATC- $3^{\prime}$. Samples represented dissected retina except at E13.5, at which age whole eye was used. Western blot analysis was performed on 10 or $20 \mu \mathrm{g}$ samples of retinal proteins using antibodies for ROR $\beta$ (rabbit polyclonal, 1/1000, Diagenode pAbRORbHS100) and actin (mouse monoclonal, 1/5000, Millipore MAb1501) with chemiluminescent detection ${ }^{44}$.

In situ hybridization and immunohistochemistry. Digoxigenin-labelled antisense and sense riboprobes were used for in situ hybridization on $10 \mu \mathrm{m}$ retinal cryosections with colorigenic detection as described ${ }^{44}$. For immunostaining, $10 \mu \mathrm{m}$ cryosections were incubated overnight with primary antibody at $4{ }^{\circ} \mathrm{C}$, then 
incubated with fluorescent-conjugated second antibody for $1 \mathrm{~h}$ at room temperature, gently washed three times in 1xPBS before addition of mounting medium. Antibodies and dilutions are listed in Supplementary Table S1. Double analysis for gfp and PCNA (or BrdU) required pre-treatment of sections in $2 \mathrm{M}$ $\mathrm{HCl}$ at room temperature for $10 \mathrm{~min}$, followed by neutralization in $0.1 \mathrm{M}$ sodium borate buffer for $10 \mathrm{~min}$ before addition of antibody against PCNA or BrdU. For flatmounts, the eye was fixed in $4 \%$ PFA at $4{ }^{\circ} \mathrm{C}$ for $1 \mathrm{~h}$. The cornea, lens and pigmented epithelium were removed, then the retinal cup incubated with antibody in blocking buffer for 2-3 days at $4{ }^{\circ} \mathrm{C}$, washed several times in PBS for $6 \mathrm{~h}$, then incubated with second fluorescent antibody for 1 day. The retina was washed in PBS for $2 \mathrm{~h}$, cut peripherally with 3-5 incisions then flattened on a slide. For BrdU labelling, pregnant female mice or neonatal pups were injected intraperitoneally with $20 \mu \mathrm{g} \mathrm{BrdU/g}$ weight from a $10-\mu \mathrm{g} / \mu \mathrm{l}$ stock solution $1 \mathrm{~h}$ before eye dissection. For immunofluorescence, a Leica laser scanning confocal microscope analysed $0.5 \mu \mathrm{m}$ planar images stacked to a total $4 \mu \mathrm{m}$ thickness for retinal flatmounts or sections of electroporated retinas, or a single $0.5 \mu \mathrm{m}$ plane for other sections. Image brightness and contrast were adjusted using ImageJ (NIH, Bethesda, MD). Cell count data represent means \pm s.d. Statistical analyses of cell counts were performed using Student's two-tailed $t$-test to compare $1 \mathrm{~g} / \mathrm{lg}$ versus $+/+$ samples, or test versus control samples in electroporation experiments. For histology, $3 \mu \mathrm{m}$ methacrylate plastic sections near the vertical mid-line of the eye were stained with hematoxylin and eosin ${ }^{44}$.

\section{Reporter plasmid constructs and luciferase assays. Ptfla promoter and} enhancer fragments from C57BL/6J mouse DNA were inserted into pREP4 luciferase reporter vector. Mutations were introduced by site-directed mutagenesis into the reporter vectors using oligonucleotides to change the RORE, F1 and F2 Foxn response elements as follows (changed bases in bold and italics within the underlined core motifs): RORE-mutation 5'-GGGTCTGAAACTGAATTCAAG CGATTAGCA- $3^{\prime}$; F1 mutation 5'-GAGCTAGGGGTTGGGGCA $\overline{\text { GGAGCAGC }}$

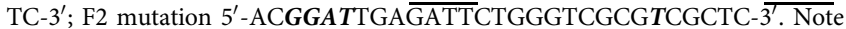
that for F1 and F2 elements, both candidate Foxn response motifs (ACGC) were changed in each element. Mouse ROR $\beta 1$ and Foxn 4 cDNAs were expressed from pSG5 or pCDNA3.1 vectors transfected into $293 \mathrm{~T}$ cells in 24 -well plates in mixtures containing $100 \mathrm{ng}$ reporter, $5 \mathrm{ng}$ pSV-RL renilla control plasmid, $400 \mathrm{ng}$ expression plasmid and carrier DNA to a total of $800 \mathrm{ng}$ DNA with $2 \mu$ l Fugene HD reagent (Roche). Luciferase activity was measured $48 \mathrm{~h}$ after transfection. Samples were analysed in triplicate and each experiment was repeated three times. Data represent mean \pm s.d. Statistical analysis was performed by Student's $t$-test under different categories: (i) basal activity of each reporter in the absence of added factors was compared individually with promoter alone $(\mathrm{Pr})$ reporter, to rule out basal variations that could distort subsequent analyses of induction; none was significantly different from Pr alone $(P>0.26)$; (ii) for determination of the synergistic response of each reporter, the normalized fold induction in the presence of both ROR $\beta 1$ and Foxn 4 was compared with that in the absence of factors or in the presence of only ROR $\beta 1$ or Foxn4; (iii) to determine the activity of each enhancer fragment, the fold induction of each reporter in the presence of both factors was compared with that of promoter alone $(\mathrm{Pr})$ in the presence of both factors; (iv) to assess the result of mutagenesis of RORE, F1 or F2 in the context of $\operatorname{Pr} /$ En 0.8 , the fold induction over basal level of each mutation construct in the presence of ROR $\beta 1$ and Foxn 4 was compared with the fold induction of wild-type $\operatorname{Pr} /$ En 0.8 in the presence of ROR $\beta 1$ and Foxn 4 .

EMSA and protein co-selection analyses. EMSA was performed with $2 \mu \mathrm{g}$ of nuclear protein extract from transfected $293 \mathrm{~T}$ cells and 0.2 pmol of ${ }^{32}[\mathrm{P}]$ endlabelled probe as described ${ }^{27}$. Antibody against ROR $\beta$ or control IgG was preincubated with protein at $4{ }^{\circ} \mathrm{C}$ for $30 \mathrm{~min}$ before addition of probe, then incubated at room temperature for $15 \mathrm{~min}$. Competitor probe was added at 5 - or 50 -fold excess. For protein pull-down studies, extracts from $293 \mathrm{~T}$ cells transfected with ROR $\beta 1$ and $\mathrm{His}_{6}$-Foxn4 expression plasmids were incubated with Ni-beads for $2 \mathrm{~h}$ at $4{ }^{\circ} \mathrm{C}$ (ref. 27). The histidine tag was fused onto the C-terminus of Foxn4. Proteins were released by heating at $95^{\circ} \mathrm{C}$ then analysed by electrophoresis and western blot.

\section{References}

1. Masland, R. H. The fundamental plan of the retina. Nat. Neurosci. 4, 877-886 (2001).

2. Sidman, R. L. in The Structure of the Eye (ed. Smelser, G. K.) 487-506 (Academic Press, 1961).

3. Hinds, J. W. \& Hinds, P. L. Development of retinal amacrine cells in the mouse embryo: evidence for two modes of formation. J. Comp. Neurol. 213, 1-23 (1983).

4. Young, R. W. Cell differentiation in the retina of the mouse. Anat. Rec. 212, 199-205 (1985).

5. Voinescu, P. E., Kay, J. N. \& Sanes, J. R. Birthdays of retinal amacrine cell subtypes are systematically related to their molecular identity and soma position. J. Comp. Neurol. 517, 737-750 (2009).

6. Livesey, F. J. \& Cepko, C. L. Vertebrate neural cell-fate determination: lessons from the retina. Nat. Rev. Neurosci. 2, 109-118 (2001).
7. Brzezinski, J. \& Reh, T. A. Encyclopedia of the Eye 73-80 (Elsevier, 2010)

8. Swaroop, A., Kim, D. \& Forrest, D. Transcriptional regulation of photoreceptor development and homeostasis in the mammalian retina. Nat. Rev. Neurosci. 11, 563-576 (2010).

9. Li, S. et al. Foxn4 controls the genesis of amacrine and horizontal cells by retinal progenitors. Neuron 43, 795-807 (2004).

10. Fujitani, Y. et al. Ptfla determines horizontal and amacrine cell fates during mouse retinal development. Development 133, 4439-4450 (2006).

11. Nakhai, H. et al. Ptfla is essential for the differentiation of GABAergic and glycinergic amacrine cells and horizontal cells in the mouse retina. Development 134, 1151-1160 (2007)

12. Boije, H., Edqvist, P. H. \& Hallbook, F. Temporal and spatial expression of transcription factors FoxN4, Ptfla, Proxl, Isl1 and Lim1 mRNA in the developing chick retina. Gene Expr. Patterns 8, 117-123 (2008).

13. Jusuf, P. R. \& Harris, W. A. Ptfla is expressed transiently in all types of amacrine cells in the embryonic zebrafish retina. Neural Dev. 4, 34 (2009).

14. Dyer, M. A., Livesey, F. J., Cepko, C. L. \& Oliver, G. Prox1 function controls progenitor cell proliferation and horizontal cell genesis in the mammalian retina. Nat. Genet. 34, 53-58 (2003).

15. Inoue, T. et al. Math3 and NeuroD regulate amacrine cell fate specification in the retina. Development 129, 831-842 (2002).

16. Feng, L. et al. Requirement for Bhlhb5 in the specification of amacrine and cone bipolar subtypes in mouse retina. Development 133, 4815-4825 (2006).

17. Cherry, T. J. et al. NeuroD factors regulate cell fate and neurite stratification in the developing retina. J. Neurosci. 31, 7365-7379 (2011).

18. Kay, J. N., Voinescu, P. E., Chu, M. W. \& Sanes, J. R. Neurod6 expression defines new retinal amacrine cell subtypes and regulates their fate. Nat. Neurosci. 14, 965-972 (2011).

19. Jin, K., Jiang, H., Mo, Z. \& Xiang, M. Early B-cell factors are required for specifying multiple retinal cell types and subtypes from postmitotic precursors. J. Neurosci. 30, 11902-11916 (2010).

20. Mo, Z., Li, S., Yang, X. \& Xiang, M. Role of the Barhl2 homeobox gene in the specification of glycinergic amacrine cells. Development 131, 1607-1618 (2004).

21. Elshatory, Y. et al. Islet-1 controls the differentiation of retinal bipolar and cholinergic amacrine cells. J. Neurosci. 27, 12707-12720 (2007).

22. Ding, Q. et al. BARHL2 differentially regulates the development of retinal amacrine and ganglion neurons. J. Neurosci. 29, 3992-4003 (2009).

23. Chen, D. et al. Rb-mediated neuronal differentiation through cell-cycleindependent regulation of E2f3a. PLoS Biol. 5, e179 (2007).

24. Cherry, T. J., Trimarchi, J. M., Stadler, M. B. \& Cepko, C. L. Development and diversification of retinal amacrine interneurons at single cell resolution. Proc. Natl Acad. Sci. USA 106, 9495-9500 (2009).

25. Jiang, H. \& Xiang, M. Subtype specification of GABAergic amacrine cells by the orphan nuclear receptor Nr4a2/Nurr1. J. Neurosci. 29, 10449-10459 (2009).

26. Andre, E. et al. Disruption of retinoid-related orphan receptor $\beta$ changes circadian behavior, causes retinal degeneration and leads to vacillans phenotype in mice. EMBO J. 17, 3867-3877 (1998).

27. Srinivas, M., Ng, L., Liu, H., Jia, L. \& Forrest, D. Activation of the blue opsin gene in cone photoreceptor development by retinoid-related orphan receptor $\beta$. Mol. Endocrinol. 20, 1728-1741 (2006).

28. Jia, L. et al. Retinoid-related orphan nuclear receptor ROR $\beta$ is an early-acting factor in rod photoreceptor development. Proc. Natl Acad. Sci. USA 106, 17534-17539 (2009).

29. Andre, E., Gawlas, K. \& Becker-Andre, M. A novel isoform of the orphan nuclear receptor ROR $\beta$ is specifically expressed in pineal gland and retina. Gene 216, 277-283 (1998).

30. Chow, L., Levine, E. M. \& Reh, T. A. The nuclear receptor transcription factor, retinoid-related orphan receptor $\beta$, regulates retinal progenitor proliferation. Mech. Dev. 77, 149-164 (1998).

31. Barton, K. M. \& Levine, E. M. Expression patterns and cell cycle profiles of PCNA, MCM6, cyclin D1, cyclin A2, cyclin B1, and phosphorylated histone H3 in the developing mouse retina. Dev. Dyn. 237, 672-682 (2008).

32. Luo, H. et al. Forkhead box N4 (Foxn4) activates Dll4-Notch signaling to suppress photoreceptor cell fates of early retinal progenitors. Proc. Natl Acad. Sci. USA 109, E553-E562 (2012).

33. Masui, T. et al. Transcriptional autoregulation controls pancreatic Ptfla expression during development and adulthood. Mol. Cell Biol. 28, 5458-5468 (2008).

34. Meredith, D. M., Masui, T., Swift, G. H., MacDonald, R. J. \& Johnson, J. E. Multiple transcriptional mechanisms control Ptfla levels during neural development including autoregulation by the PTF1-J complex. J. Neurosci. 29, 11139-11148 (2009).

35. Schlake, T., Schorpp, M., Nehls, M. \& Boehm, T. The nude gene encodes a sequence-specific DNA binding protein with homologs in organisms that lack an anticipatory immune system. Proc. Natl Acad. Sci. USA 94, 3842-3847 (1997).

36. Matsuda, T. \& Cepko, C. L. Analysis of gene function in the retina. Methods Mol. Biol. 423, 259-278 (2008). 
37. Kautzmann, M. A., Kim, D. S., Felder-Schmittbuhl, M. P. \& Swaroop, A Combinatorial regulation of photoreceptor differentiation factor, neural retina leucine zipper gene NRL, revealed by in vivo promoter analysis. J. Biol. Chem. 286, 28247-28255 (2011).

38. Montana, C. L. et al. Transcriptional regulation of neural retina leucine zipper (Nrl), a photoreceptor cell fate determinant. J. Biol. Chem. 286, 36921-36931 (2011).

39. Yu, Y. et al. The nuclear hormone receptor Ftz-F1 is a cofactor for the Drosophila homeodomain protein Ftz. Nature 385, 552-555 (1997).

40. Eberl, G. et al. An essential function for the nuclear receptor RORgamma(t) in the generation of fetal lymphoid tissue inducer cells. Nat. Immunol. 5, 64-73 (2004).

41. $\mathrm{Ng}$, L. et al. A thyroid hormone receptor that is required for the development of green cone photoreceptors. Nat. Genet. 27, 94-98 (2001).

42. Bunting, M., Bernstein, K. E., Greer, J. M., Capecchi, M. R. \& Thomas, K. R Targeting genes for self-excision in the germ line. Genes Dev. 13, 1524-1528 (1999).

43. Kim, D. S., Matsuda, T. \& Cepko, C. L. A core paired-type and POU homeodomain-containing transcription factor program drives retinal bipolar cell gene expression. J. Neurosci. 28, 7748-7764 (2008).

44. Ng, L. et al. Two transcription factors can direct three photoreceptor outcomes from rod precursor cells in mouse retinal development. J. Neurosci. 31, 11118-11125 (2011)

\section{Acknowledgements}

We thank C. Stewart for W9.5 ES cells, M. Capecchi for plasmid pACN, D. Kim, T. Badea and M. Ma for advice and assistance and K. Kelley for blastocyst injections. This work was supported by the NIDDK and NEI intramural research programs at the NIH and a grant from the KaroBio Foundation.

\section{Author contributions}

H.L. and D.F. designed experiments. H.L., S.-Y.K., Y.F., X.W., L.N., A.S. and D.F. performed experiments and analysed data. H.L. and D.F. wrote the manuscript.

\section{Additional information}

Supplementary Information accompanies this paper at http://www.nature.com/ naturecommunications

Competing financial interests: The authors declare no competing financial interests.

Reprints and permission information is available online at http://npg.nature.com/ reprintsandpermissions/

How to cite this article: Liu, H. et al. An isoform of retinoid-related orphan receptor $\beta$ directs differentiation of retinal amacrine and horizontal interneurons. Nat. Commun. 4:1813 doi: 10.1038/ncomms2793 (2013). 